\title{
AN AGENCY THEORY PERSPECTIVE ON THE OWNER / MANAGER RELATIONSHIP IN TOURISM-BASED CONDOMINIUMS
}

\author{
Chris GUILDING \\ Service Industry Research Centre and \\ School of Accounting \& Finance \\ Jan WARNKEN \\ School of Environmental \& Applied Sciences \\ Allan ARDILL \\ School of Law \\ Liz FREDLINE \\ Service Industry Research Centre and \\ School of Tourism \& Hospitality Management \\ Griffith University - Gold Coast Campus \\ Queensland \\ AUSTRALIA
}

Contact details:

Associate Professor Chris Guilding

School of Accounting and Finance

Griffith University - Gold Coast Campus

PMB 50 Gold Coast Mail Centre

Queensland 9726

AUSTRALIA

Tel: 0755528790

Fax: 0755528068 


\title{
AN AGENCY THEORY PERSPECTIVE ON THE OWNER / MANAGER RELATIONSHIP IN TOURISM-BASED CONDOMINIUMS
}

\begin{abstract}
This paper draws on field study data to provide an examination of the condominium owner / manager relationship in the Australian tourism context. Although there has been considerable growth in tourism accommodation owned through strata-title, no research examining the somewhat idiosyncratic relationship between unit owners and resident managers has been found in the literature. The peculiar nature of the relationship underlines its significance as a context in which to apply the agency theoretical model. As Australian condominium resident unit managers provide letting and caretaker services for condominium unit owners, it appears the relationship can be justifiably viewed as a principal-agent exchange (Mills, 1990).

The study specifically focuses on strata title condominiums located in major tourism regions. This sub-sector of the condominium management industry was chosen for study because it exhibits several key attributes distinguishing it from the non-tourist based condominium sector. For example, two different parties represent the principal (resident owners and investor owners), also a significant proportion of a resident manager's work relates to the management of short-term holiday unit letting. In light of the particular agency relationship dynamics arising in large tourist-based condominium governance, several suggestions concerning the legal environment of the industry are provided.
\end{abstract}

Key words: Tourism, condominium, agency theory. 


\section{AN AGENCY THEORY PERSPECTIVE ON THE OWNER / MANAGER RELATIONSHIP IN TOURISM-BASED CONDOMINIUMS}

\section{INTRODUCTION}

This study is concerned with the governance of condominium complexes (sometimes referred to as "strata-titled” complexes). In Australia and New Zealand, the typical condominium complex comprises multiple dwelling units in a shared community title scheme whereby there are as many private owners of units as there are lots within a scheme. These complexes can assume a variety of physical forms. They can be designed as detached villas, duplexes or townhouses; as low rise (typically 2-3 storeys) apartment complexes comprising usually around 6-12 units; ${ }^{1}$ or as high rise apartment complexes generally comprising eight or more storeys and comprising many units (can be up to 500 or more units).

In Australia, there are 35,000 holiday apartments in condominium complexes with more than 15 apartments in the holiday letting pool (Australian Bureau of Statistics, 2002). If we impute an average value of AUS \$250,000 per unit, this represents an overall investment of AUS $\$ 8.75$ billion in the tourism accommodation sector. Due to Australian income tax provisions that provide a tax deduction for expenditure related to investment properties, most units are owned by individuals. In the 2001/2002 financial year, this investment generated AUS \$932 million in rental income (i.e., about one fifth of total

\footnotetext{
${ }^{1}$ Some of these low storey complexes can comprise as many as 100 units, however.
} 
accommodation sector earnings).

The majority of financial institutions that finance condominium complex developments require $25-50 \%$ of the apartments to be sold off the plan (i.e. prior to building commencement), before releasing the capital required to complete the major building works. Without investor owners who plan to use their apartments for holiday lettings, the number of potential buyers would be substantially lower and initial 'off the plan' sales would take much longer to reach the required quota. Furthermore, holiday apartments are often purchased as a means to diversify investment portfolios for retirement funds. Appropriate governance of condominium complexes is therefore not only a tourism management issue, it also carries more general socio-economic implications.

The last quarter of a century has seen major growth in the provision of tourist accommodation in condominium complexes. While one tends to think first of hotels when conceiving of tourist accommodation, this is becoming an out-dated notion as condominiums now represent the primary form of accommodation in many tourist resorts such as Australia’s Gold Coast (Warnken, 2002, Warnken et al., 2003). In light of this condominium tourist accommodation growth, relative to the volume of research conducted into hotel management, there is a startling paucity of research concerned with condominium management. The study reported herein was conducted in light of this apparent gap in the literature.

The study draws on the agency theory framework to provide insights into the idiosyncratic nature of condominium governance and also the conflicts that can arise between a condominium complex's unit owners and its resident manager. This appraisal 
is conducted in the context of condominiums located in tourist regions. In tourist region condominiums there are two main types of unit owner: resident owners and investor owners that sub-let their units to short-term stay holiday-makers. Tourist region condominiums also carry the additional dynamic of a broadened resident manager responsibility due to the provision of a short-term letting management service.

The validity of drawing on the agency theory framework in connection with condominium operations becomes evident when comparing the nature of a hotel's operational and logistical operations with those of a tourist-based condominium. Data for this study has been collected from parties involved with large condominiums located, in the main, close to Australia's Gold Coast. This area represents an archetypal tourist centre with a high density of high rise buildings located adjacent to a commercially developed beach-front. For some time it has been widely acknowledged to represent Australia's premier tourist destination (Russell and Faulkner, 1999). Condominiums in tourist regions can be compared to hotels due to the provision of a reservation management and room cleaning service. From an operational perspective, the primary difference between a tourist based condominium and a hotel is the fact that condominiums generally provide no or minimal food and beverage services other than self-catering facilities. ${ }^{2}$ A hotel represents a commercial setting where the conventional owner / manager relationship that has been the primary subject of agency research can be readily applied. Similarly, the conventional workings of a condominium complex signifies an agency relationship where the wealth seeking objectives of unit owners have

\footnotetext{
${ }^{2}$ A particular aspect of the provision of a short-term stay condominium unit may in fact give rise to more complex labour management implications than is the case for hotel guest management. As condominiums provide self-catering facilities, it is to be expected that in many cases the time taken to clean a unit following a guest's departure will be greater than the time taken to clean a hotel room following a hotel guests departure. The provision of self-catering facilities also carries implications for maintenance and control of self-catering infrastructure.
} 
to be reconciled with the wealth seeking objectives of a resident manager. As will be noted below, however, the governance arrangement typically implemented in Australian condominiums departs radically from the generally applied owner / manager governance structure evident in most Western commercial organisations.

The remainder of the paper is organised as follows. The next section overviews the agency theory model and the nature of research conducted within the agency theory tradition. Following this, the particular nature of agency relationships apparent in the context of condominium management are outlined. The qualitative data collection research methods applied and also findings made in connection with the specific issues arising in this relationship are then presented. The paper concludes with a summary of the main findings, a discussion of the practical implications arising from the study and an outline of some research initiatives that can build on the study reported herein.

\section{AGENCY THEORY}

Agency theory concerns exchanges where one party, the principal (typically represented by the owner(s) of a business), delegates work to a second party, the agent (typically represented by a manager or some other employee of the business owned by the principal). It attempts to draw out contractual problems that can arise as a result of agents acting opportunistically when their interests depart from those of the principal (Berle and Means, 1962; Jensen and Meckling, 1976). These problems are exacerbated where information asymmetry favouring the agent exists. ${ }^{3}$

\footnotetext{
${ }^{3}$ Information asymmetry arises when one party has access to information that the second party cannot
} 
Agency theory has been a popular conceptual framework for researchers interested in conflicts of interest, incentive problems and also mechanisms for managing incentive problems (Eisenhardt, 1989; Bohren, 1998; Lambert, 2001). ${ }^{4}$ Identification of an organisational setting where there is a potential for conflicting interests between one or more parties is a fundamental precept of agency theory modeling. Lambert (2001) notes four typical reasons for agent-principal conflict arising. These are: (i) there is a potential for effort aversion by the agent (eg., a manager may well experience a desire to not apply an optimal effort when completing his/her work), (ii) the agent can use his work situation as an opportunity to divert resources towards his own personal benefit, (iii) there can be differential time horizons i.e., while an owner may see their involvement in the agency relationship in the context of ten or more years, the agent might have little concern with the long-term implications of his actions as he does not expect to be in the relationship over the long-term, (iv) there may be different attitudes to risk held by the principal and the agent.

Two streams of research drawing on agency theory can be identified. Jensen (1983) refers to these as the positivist and the principal-agent streams. Research conducted within the positivist tradition has tended to identify and describe principal-agent relationships where conflicting interests are evident and to comment on governance mechanisms implemented to police the self-interested agent. Eisenhardt (1989) sees several key studies falling within this research tradition. These include Jensen and Meckling's (1976) work concerned with corporate ownership structures, Fama and Jensen's (1983) focus on the board of directors' role and senior executive opportunism, and studies concerned with

access.

${ }^{4}$ See Kakabadse and Kakabadse (2001), La Porta et al (1999), Letza and Smallman (2001), Stoney and Winstanley (2001) and Zingales (2000) for some recent critiques of this literature. 
somewhat controversial practices such as golden parachutes and corporate raiding (eg., Jensen, 1984; Jensen and Roeback, 1983). Principal-agent researchers are more concerned with the development of a general agency model. Studies characteristic of this second research tradition tend to be based on theoretical deduction and mathematical proof. As this study concerns the application of agency theory to a particular organisational context, it relates most closely to the positivist agency research tradition. ${ }^{5}$

Agency theorists refer to two costs that a principal can incur when attempting to manage an agent who has the benefit of asymmetric information: (1) costs of monitoring and (2) costs of metering (Williamson, 1985; Sharma, 1997). Monitoring costs are incurred when the principal attempts to monitor an agent's behaviour. If an agent is observed to be acting in ways that conflict with the spirit of the relationship (ways that are detrimental to the interests of the principal), the principal can impose sanctions on the agent. If it is costly to monitor the agent's actions, a principal may choose to focus on metering the outcomes of the agent's actions. For example, a widely-used outcome based contract is evident when workers are reimbursed on a piece-rate basis. A key distinction between the behaviour monitoring approach and the outcome metering approach is that the latter results in risk being transferred from principals to agents. When outputs are measured, the agent is exposed to the risk of uncontrollable factors (e.g., random machine break-down, faulty raw materials, changing competitive environment), affecting the appraised performance. It is a fundamental tenet of agency theory that the costs of monitoring and metering incurred by the principal should not outweigh the principal's derived benefit from appraising the agent's performance. Despite actions that a principal can take to influence the performance of an agent, research has shown the degree to which principals

\footnotetext{
${ }^{5}$ Unlike most studies in this research tradition, however, this study does not focus on the shareholder /
} 
can be at the mercy of agents (Bazerman et al, 1992; Kesner et al, 1994).

The agency model has been applied in a range of transactional settings concerned with a variety of issues (e.g., vertical integration [Walker and Weber, 1984], executive compensation [Baker, Jensen and Murphy, 1988], tender offers [Cotter and Zenner, 1994]). It has also been used in a variety of disciplinary contexts (e.g., accounting [Demski and Feltham, 1978], marketing [Basu et al, 1985, Bergen et al., 1992] and organisational behaviour [Eisenhardt, 1988]). As the relationships that researchers have appraised from an agency perspective are broad, following the lead of Sharma (1997), the particular agency issues of interest in this study will be appraised in the context of the owner-manager agency relationship which has dominated agency research (Eisenhardt, 1989; Walsh and Seward, 1990).

\section{THE OWNERSHIP / MANAGEMENT STRUCTURE OF QUEENSLAND}

\section{CONDOMINIUMS}

Agency theory would appear to represent a particularly pertinent framework to draw upon when considering incentive issues arising in the context of condominium management. Eisenhardt notes:

"(T)he domain of agency theory is relationships that mirror the basic agency structure of a principal and an agent who are engaged in co-operative behavior, but have differing goals and attitudes toward risk” (1989: 59).

It would certainly appear that the nature of the condominium owner / manager 
relationship is one exemplifying two parties engaged in a scenario representing a highly co-operative venture. In addition to the factors normally present in the archetypal principal / agent relationship of the corporate world, two further factors highlighting a heightened need for co-operation are present in the condominium unit-owner / manager relationship. Firstly, with respect to condominium resident owners, the additional dynamic of proximity of domicile between the principal and agent is also evident. This is because in Australia, the manager usually owns and resides in the designated resident manager unit within the condominium complex. This signifies that the condominium owner / manager relationship moves well beyond the confines of a working relationship restricted to normal business hours. Secondly, the financial implications at stake for both the principal and agent would appear to be heightened in most condominium ownermanager relationships. In the vast majority of corporate owner / manager relationships most owners have a relatively small proportion of personal wealth at stake in any particular corporate enterprise due to the common investment strategy of investment portfolio diversification. Also, most employees make no financial investment in their job (although loss of job may well carry fundamentally significant financial implications for many employees). Compare this with the owner / manager situation in a condominium complex. Purchase of a condominium unit represents a significant investment that in many cases will constitute the bulk of an individual's personal wealth, particularly where the investor intends to occupy the purchased apartment. Also, in Australia, condominium managers buy the rights to manage a building as well as title to the resident manager's unit. This model was developed in an attempt to increase the resident manager's general interest in the building thereby improving his/her overall motivation to act effectively as caretaker. Some recent sales of condominium resident manager rights in large Australian complexes have commanded prices in excess of a million dollars. As a result, it is evident 
that the financial stakes of the two parties involved in a condominium owner / manager relationship are considerably greater than is the case in the context of the conventional corporate owner / manager relationship.

The nature of the unit-owner / resident manager relationship is depicted in Figure 1. Mediating the relationship between owners and the resident manager is a body corporate committee that is elected by the unit owners. The role of the body corporate committee parallels the role of a board of directors in a corporation as it serves the interest of the principal (i.e., the owners) in managing the agents (i.e., managers in a corporation and the resident manager in a condominium). Figure 1 highlights the two distinct unit owner categories mentioned earlier: resident owners and investor owners. This distinction between unit owner types is significant, and its practical implications will be elaborated upon in the paper’s "findings” section.

Insert Figure 1 about here

One distinguishing facet of the interest of resident owners and investor owners is evident from Figure 1. An investor owner can be expected to be primarily interested in the resident manager's sub-letting performance. A resident owner, however, gains no financial advantage from the success of the resident manager's sub-letting performance. Many resident owners might actually desire that the condominium complex has a low occupancy level and therefore derive satisfaction from a resident manager proving to be ineffective with respect to sub-letting activities. The resident owner can be expected to be more narrowly interested in the resident manager's performance with respect to efficiently and effectively completing his caretaking responsibilities (i.e., maintenance 
and cleaning of the condominium building and grounds).

The body corporate committee's activities include overseeing a resident unit manager's performance, setting and administering an operational budget and setting and raising levies for a sinking fund established for the purpose of periodic major building maintenance expenditure.

As already noted, in most parts of Australia the resident unit manager buys the rights to manage the building. Management right holders in a tourism complex usually derive most of their return in the form of sub-letting commissions for renting units assigned to the holiday letting pool. In theory, sub-letting rights can be withdrawn by individual investor owners at any time and transferred to an outside real estate agent at short notice. Further, should the resident unit manager's performance with respect to his building caretaking performance be deemed unsatisfactory, a simple voting majority of unit owners can elect to terminate his building service contract.

\section{RESEARCH METHOD}

The empirical data collection method employed comprised two distinct phases. Initially, the research team hosted a panel discussion of parties interested in condominium ownership and management. The purpose of this initial data collection phase was to strengthen the research team's appreciation of ownership, governance and operational management issues arising in large condominium complexes located in tourist regions. The discussion took place in the context of a two and a half hour working lunch hosted in a Gold Coast hotel seminar room. Panel discussants were informed of the research team's 
interest in condominium development and management in tourist regions. To provide greatest scope for the invited panelists to influence the research team's agenda, the meeting was conducted in a relatively unstructured manner with all participants being encouraged to raise issues they felt pertinent to an academic inquiry of the industry. The panel comprised the following interested parties:

- A representative of the Queensland Resident Accommodation Managers Association,

- A representative of the Body Corporate Managers Institute of Queensland,

- Real estate agents with a specialism in the sale of condominium strata title units,

- A representative of the hotel / tourism accommodation management industry.

The second stage of empirical data collection involved a slightly more focussed interview approach. Two group interview sessions were held with three representatives of the Queensland Unit Owners Association. In addition, two interviews were held with a freelance consultant who provides specialist advice in connection with condominium management and ownership (this individual has more than twenty years of experience in the industry). All these interviews were audio-taped and ran in total for more than ten hours. This research approach was taken as some of the issues addressed appeared relatively sensitive. In the course of conducting the interviews, considerable rapport developed between members of the research team and the interviewees. It is believed this rapport has facilitated greater appreciation of some of the key issues confronting the industry as the interviewees became noticeably more candid as the interviews progressed. Despite this, on a couple of occasions the interviewees requested that the tape recorder be turned off for portions of the meetings. It should also be noted that the research team's 
appreciation of key issues in the condominium unit owner / manager agency relationship has been further informed by numerous casual conversations conducted with past and present condominium unit owners and other parties involved in condominiums (e.g., property developers and sub-contractors providing condominium maintenance services). ${ }^{6}$

\section{RESULTS AND DISCUSSION}

In this section observations pertinent to providing insights into the particular nature of the condominium unit owner / resident manager relationship are presented. Initially the ways in which the condominium unit owner / resident manager relationship departs from the archetypal corporate owner / manager agency relationship are described. Following this, Lambert's (2001) four point classification of typical factors accounting for principal / agent conflict is drawn upon to provide a framework facilitating further appreciation of the problematical nature of the condominium unit owner / manager relationship. Following the lead provided by several interviewees, when talking of "Resident Unit Mangers" the acronym "RUM” will be used.

5.1 The idiosyncratic nature of the condominium unit owner / resident manager agency relationship

In conventional agency theory modeling the principal / agent relationship is conceived in

\footnotetext{
${ }^{6}$ Given the nature of the subject matter under study, judgement had to be exercised with respect to which parties would yield the most substantial insights into the owner / resident unit manager relationship. The approach that was taken involved initially casting a wide data collection net in terms of parties represented, in order to secure representation of a range of perspectives. As discussions proceeded, it was then determined that more focussed and narrower representation should be sought in repeated interviews in order that trust could develop between the interviewers and interviewees. Owners had greater representation in the interviews conducted than RUMs because much of the agency framework concerns how the principal can secure stronger control over the agent.
} 
terms of two parties where each party comprises a set of relatively homogeneous agents with uniform self-maximising interests. As already discussed and highlighted in Figure 1, this does not appear to be the case in tourism-based condominium management, as the principal is represented by two distinct groups with substantially different interests in regard to the role of the RUM. This view of principals as a heterogeneous group with competing interests highlights a significant departure from the conventional agency model. Despite this departure, in Australian legislation pertaining to condominium management there appears to be limited acknowledgement of the potential for conflict between resident and investor owners.

The different perspectives of the two owner types appear to have a major bearing on the relationship between a RUM and an individual owner. Because both the investor owners and the RUM derive a substantial portion of their investment returns from letting out apartments to holiday makers, their goals appear to be relatively well-aligned. The goals of the RUM and resident owners can be characterised more by divergency than convergency, however. In some cases this goal incongruity can result in resident owners sensing an antagonistic manner from the RUM. This antagonism appears to result from RUM's earning no letting agency income from the resident owner units. One interviewee commented:

“We've got friends who own a unit and we go up there a bit and the first time we walked in the manager there was really nice to us. Then he realised where we were going and now he treats us like dirt because he's getting no money. Our friends don't rent their unit out. They're not on the rent file so he's not interested and honestly its terrible.”

Such behaviour, particularly if extended to tourists using apartments hired out by an 
outside (i.e. real estate) agent, could provide a serious impediment to word-of-mouth promotion which is one of the most critical marketing instruments in the tourism sector.

Berle and Means (1967) distinction between active and passive roles of the principal appears pertinent to a consideration of the differing interests of resident and investor owners. With respect to the execution of the RUM's caretaker role, resident owners are likely to be the much more active party. This is because the cost of monitoring the performance of the caretaker role will be much less for the resident owner. Due to proximity of domicile, a resident owner will be readily able to see the nature and outcome of the RUM's caretaking effort. Further, as the resident owner's quality of life will be directly affected by the standard of the RUM's caretaking service provided, it is to be expected that resident owners will have a greater propensity to complain should the caretaking performance fall below what is deemed acceptable. Investor owners can also suffer from a decline in a RUM's caretaking performance due to the adverse implications for sub-letting occupancy levels. This link between sub-letting performance and caretaking performance is unlikely to be apparent to most investor owners due to the range of parameters affecting occupancy levels, e.g., a general decline or stagnation in a region's visitor numbers. As a result, relative to resident owners, investor owners are more passively engaged with the aesthetic impact of a RUM's caretaking performance. As already noted, investor owners will directly experience the results of a RUM's poor sub-letting efforts and (where these are clearly evident) are often forced to actively find a solution to this problem. By comparison, resident owners are likely to remain passive in regard to issues that have no, or even positive, effects on their personal welfare.

This inconsistency of the interests of resident and investor owners raises the potential of a 
power struggle in terms of representation on the body corporate committee. As indicated earlier, members of the sub-letting pool of owners can, by a simple voting majority, serve a nine months notice to terminate the RUM's sub-letting contract under current Queensland legislation. As, in most large tourism condominium complexes, income earned from sub-letting constitutes the vast bulk of the RUM's total income, termination of the sub-letting contract signifies a greatly diminished incentive for the RUM to remain in the building and continue to undertake caretaker duties. If, however, the RUM elects to remain in the building and continue to undertake caretaking services, a somewhat unworkable situation arises with respect to the sub-letting function. This is because the RUM's property ownership includes the office space dedicated to the sub-letting management function. If this scenario arises, it can be difficult for investor owners to arrange effective management of the sub-letting function. As a result, if the RUM appears likely to resist leaving the building following a termination of sub-letting rights, the investor owners may be reluctant to invoke their right to terminate a sub-letting contract and try to attract long-term tenants or sell their apartment and move their investment outside the tourism industry. Both scenarios signify a withdrawal of resources from the tourism industry.

A second idiosyncratic aspect of the condominium owner / resident manager agency relationship concerns the degree to which investor owners can be seen to be in direct competition with one another. In the tourism condominium context, revenue from investment (i.e. rent collected from holiday lettings) is not pooled across all relevant apartments but awarded by the RUM, the agent, to the individual owner who owns the particular apartment that has been sublet. This particular dynamic lies in stark contrast to most other corporate ownership structures where returns on investment are awarded as a 
percentage of the business's overall earnings, weighted in accordance with the number of shares held by the investor. This direct involvement of the agent, the RUM, in the allocation of returns earned opens up the possibility of collusion between a particular investor owner and the RUM, i.e. one individual principal and the agent. An investor owner might be motivated to offer a RUM inducements in order to increase the occupancy rate of his or her unit. While comments made by interviewees suggest this potential is significant, two factors may curtail a RUM's propensity to unevenly allocate rental bookings across the sub-letting pool:

a. As a result of a poor sub-letting performance, an investor owner might sell their unit and the purchaser of the unit might withdraw it from the letting pool.

b. As a result of poor sub-letting performance, an investor owner might withdraw his unit from the letting pool. The incidence of this outcome is likely to be limited by the fact that the investor owner would have to either move into the unit, or personally manage its letting.

More importantly though, the influence wielded by the RUM in the allocation of investor returns provides him/her with considerable power that can be exploited to secure proxy votes from interstate owner investors. As noted earlier, in Queensland a RUM becomes owner of a unit (typically on the ground floor) under a conventional management rights agreement. Ownership of a unit confers the right to attend and vote at unit owners' meetings. Many investor owners live far from the unit they own, however, and it is therefore not easy for them to attend owners' meetings. In many aspects of the day-to-day management of holiday units, the RUM is the first point of contact for the owner investor 
and therefore frequently becomes a key source of information. As it is in the interests of investor owners to maintain a positive relationship with a RUM (as their primary point of contact and key arbiter in the allocation of returns), it is common for investor owners to assign their proxy voting rights over to the RUM. The propensity of RUMs to control considerable investor owner voting rights at owner meetings underlines a fundamentally significant factor that can contribute to a schism between resident and investor owners. It also highlights a fundamental breakdown in accountability. The RUM is accountable to the body corporate committee as the elected representatives of the owners, yet the RUM can have considerable influence with respect to who is elected to the body corporate committee, and ultimately how the entire building is operated. Practically all interviewees concurred that assignment of proxies to RUMs is not uncommon and that it can contribute to a gradual deterioration of the building due to a loss of RUM accountability.

\section{$\underline{5.2 \text { Potential for effort aversion by the RUM (moral hazard) }}$}

Moral hazard can arise when owners and the RUM have different interests and the owners cannot determine whether the RUM has acted appropriately. On several occasions representatives referred to owner apathy. As no recompense is earned for services provided as a member of a body corporate committee, many owners may feel reluctant to becoming involved in closely monitoring the caretaking performance of a RUM. From field data collected, it appears many owners feel considerable reluctance to initiate any sanctioning of a RUM. When referring to this reluctance one interviewee commented:

“Owners go weak at the knees when it comes to admonishing a resident manager”. 
The propensity for owner apathy appears to be greatest in large buildings where owners might well feel that the amount of personal benefit they can derive from an improved RUM service is insufficient to justify exertion of personal effort. For a given increase in a RUM's effort, a unit owner in a 100 unit complex would only derive $1 \%$ of the benefit resulting from the greater RUM effort. In a 20 unit complex, however, a unit owner would derive $5 \%$ of the benefit resulting from an improved RUM performance. Smaller complexes would also appear to have a greater potential to develop an "esprit de corps" amongst the owners, as opposed to a "number in the crowd" culture that can be expected to develop in a large condominium complex with a diffuse ownership. Unit owner apathy was an issue repeatedly referred to in the interviews. The following quotes typify comments made:

"We've got our AGM coming up in a week or so and one of the owners rang me and said 'I see there's two quotes here. How can we be sure that the work needs to be carried out?'. I said that I can assure you we wouldn’t be carrying out $\$ 30,000$ worth of work on a building that didn't need to be carried out. All you need do is go up there and have a look at the building and you'll see what it needs. I said how long since you've been there? He lives here in Brisbane. Its only 1 hour and 10 minutes to the Sunshine Coast and they never go there”.

“Some of the unit owners aren’t even interested in having a look at a budget.... We are lucky to get a quorum. Last year we had to ring someone and get them to fax their proxy so that we could have a quorum for our AGM. We've got 30 units.... We only need to have eight people”. 
“We've got a situation here where there's one or two resident owners who know about this crap. The rest of them are ignorant and apathetic members of the mushroom club who are part of the diffuse ownership of the building. You can't get them to collaboratively agree on anything”.

The potential for a sub-standard performance with respect to the RUM's sub-letting activities would appear to be constrained by the commission received by the RUM for sub-letting revenue earned. If, however, a RUM's sub-letting performance is widely perceived to be deficient, each investor owner may feel disinclined to discuss the matter with the RUM. This is because a complaint might damage the investor owner's relationship with the RUM and result in a decline in the investor owner's share of the sub-letting pool’s occupancy levels.

One of the interviewees traced a problem of loosely drafted RUM contracts to a financial incentive for condominium complex developers. In addition to selling off the units, the developer also sells off the RUM management rights. Obviously a potential buyer of management rights is willing to pay more if the contractual rights are drafted in a manner that provides a degree of autonomy and protection to the RUM. With respect to developers he commented:

"He creates the caretaking letting agent contracts, which are done on extremely favourable terms. They are weak, wishy-washy contracts, non-performance based. You could drive a truck through the things and it wouldn't matter. You'd never catch the guy out and sue him for negligence, or breach of duties, or whatever”.

For a developer considering designing a condominium's management rights contract in a manner that caters to the interest of the RUM, it appears that the upside in additional 
revenue from selling the management rights at an inflated price is greater than the downside of reduced unit marketability. This may be because many purchasers of new units do not carefully consider the particular resident management contract applying to their complex.

In addition to moral hazard, the agency theory literature also refers to adverse selection, which concerns an agent's ability to mis-represent their ability prior to securing a job. As no approval of owners is required prior to a RUM purchasing condominium management rights, this particular facet of the agency model does not appear pertinent to the condominium management context.

\section{$\underline{5.3}$ Agent's diversion of resources in a self-interested manner}

Moral hazard problems arise when one party in an agency relationship takes an action that is damaging to the second party. The action is motivated by the first party's selfinterest and the fact that the second party has insufficient information to detect the action. A widely-acknowledged form of moral hazard that might well be significant in condominium management concerns the possibility of a RUM accepting a payment from a building service sub-contractor in return for granting a particular building service subcontract. The frequency with which this type of "back-hander" activity was referred to in connection with RUMs suggests it is not an isolated occurrence. It should be noted, however, that the owner of a small electrical servicing business commented on a particular factor constraining the incidence of sub-contracting "back-handers". He felt that many RUMs were loathe to receive back-handers because if the contract with the sub-contractor has to be terminated due to poor quality service, the sub-contractor may 
well inform the owners of the RUM's unscrupulous behaviour.

A second example of moral hazard concerns the possibility of a RUM not recording a short-term rental of a unit and failing to make the appropriate reimbursement to the unit's owner. Alternatively, a RUM may report the sub-letting of a unit, but at a rate that is below the actual amount charged to the sub-letting tenant.

A third example of moral hazard concerns the possibility of a RUM over-stating the cost of maintaining or housekeeping a room following the departure of a sub-letting guest and keeping the difference between the cost recorded to the unit owner and the actual cost remitted to the sub-contractor providing the service. One owner had a specific complaint about the amount charged by a RUM following a family holiday in his own unit:

“It cost us $\$ 183$ to clean our unit and to change the sheets on the three beds. We took blow-up beds for the extra kids and visitors, our own linen for the extra beds, our own towels etc. I can assure that the (gives his name) family are not untidy and we left the unit quite clean and ready for the benches to be cleaned and the floors to be cleaned. We had everything put away in the kitchen. \$183 to clean now that's a scam. That's where the resident managers in holiday letting can make real dough”.

\subsection{Differential owner / RUM time horizons}

If a RUM is planning to sell his management rights in the short-term, principal-agent time horizon asymmetry will result. This is because the RUM can be expected to have a shorter time perspective on his condominium involvement than the time horizon held by 
most unit owners. When taking a short-term perspective on his condominium involvement, the RUM can be expected to become particularly focussed on taking actions that will increase the marketability of the condominium's management rights. As the value of management rights are primarily determined by the sub-letting commission received by the RUM, it would seem likely that the RUM would become highly focussed on increasing sub-letting occupancy as well as accommodation rates charged. This potential highlights a further example of goal incongruency between the RUM and resident unit owners. Efforts to increase sub-letting occupancy levels may well come at the expense of a RUM's attendance to his caretaking responsibilites. This is because the RUM will become increasingly less concerned by the ability of owners to sanction him or any negative relationships that might result from a poor caretaking performance due to his planned termination of involvement with the condominium in the short-term. As it has already been noted that resident owners are most interested in a RUM's caretaking performance, the scenario of a RUM with a short time perspective on his condominium involvement represents a further particular example of a RUM's interests not being wellaligned to the interests of resident owners.

The case of an owner planning to sell their unit does not appear to raise as great a potential for owner-manager mis-alignment of interests. ${ }^{7}$ Nevertheless, the particular scenario of a condominium complex suffering from poor physical maintenance due to inadequate sinking fund levies raised from owners appears worthy of consideration. In this scenario, there may be a high propensity for a downward spiraling effect with respect to building maintenance. An increasing proportion of owners can be expected to want to

\footnotetext{
${ }^{7}$ When planning to a sell a unit, an investor owner would experience a heightened incentive to offer inducements to the RUM to increase the unit's sub-letting occupancy rate as this will have a positive impact on the unit's value as an investment property.
} 
sell their units as they become aware of the decline in the building's physical condition and the inadequacy of the condominium's accumulated sinking fund to rectify the deterioration (i.e., an increasing proportion will assume a short-term perspective on the condominium). Somewhat ironically, this increased tendency for a short-term perspective will be occurring at a time that long-term oriented actions are required to reverse the building's physical decline. The potential for a downward spiral effect being invoked becomes evident when it is recognised that owners seeking to sell their units will strongly resist any proposed increase in the sinking fund levy as this will adversely affect the marketability of their units. An increasing proportion of owners resisting an increase in sinking fund levies will accelerate a building's deterioration which will result in still further owners seeking to sell their units. The possibility of this downward spiral scenario arising underlines the importance of maintaining an accumulated sinking fund at a level that avoids the need for significant short-term increases in a condominium's sinking fund levies.

\subsection{Differential in owner / RUM attitudes to risk}

A major dimension of agency theory research concerns a principal / agent differential in attitude to risk. Agents are generally viewed as more adverse to risk due to the fact that they cannot diversify their employment. A principal (shareholder), can achieve a diversified portfolio of investments, however, and is therefore seen to be more risk neutral. A parallel to the company equity owner / company manager differential in attitudes to risk would appear to be presented in a muted form in the context of the condominium owner / manager agency relationship. 
It was noted earlier that when a principal appraises an agent's performance by metering outcomes rather than monitoring behaviour, risk associated with satisfactory completion of the task in question is assigned to the agent. Investor owners can be seen to be heavily reliant on the metering outcomes dimension of control as many will reside at a distance from the condominium that precludes the possibility of monitoring a RUM's behaviour. As the investor owner's use of outcome controls signifies heightened risk assumed by the RUM, with respect to a RUM's sub-letting activities, a degree of risk congruency between the RUM and investor owners is apparent. Some monitoring of a RUM's behaviour can be conducted by resident owners due to the proximity of their domicile to the RUM's place of work. Care taken in conducting property maintenance work and also the nature of a RUM's interactions with a building's residents (both owners and subletting tenants) represent particular facets of a RUM's behaviour that will be readily observable for resident owners. As some RUM’s can be expected to resent this relatively intrusive form of control, this dimension of a resident owner's control might well place a further strain on the resident owner / RUM relationship. Despite this, it appears likely that the majority of resident owners will base their views of a RUM's performance on the degree to which the building is maintained in a clean and well-ordered manner at a reasonable cost (i.e., outcome metering).

Similar to the company manager situation, the RUM's position represents a job that cannot be diversified. Further, by buying condominium management rights, the resident manager can be seen as exposed to significant down-side vulnerability should the condominium's letting performance decline relative to the conventional employee situation where no "job purchase" is made. For this reason, the RUM can be seen to have more at stake than an employee in a more conventional principal / agent relationship. 
Nevertheless, due to the absolute size of the investment required to become the owner of a condominium unit, the vast majority of condominium owners will not be able to achieve the same degree of investment diversification as that attainable by most shareholders of corporations.

Despite the parallels that can be drawn between the risk differential evident in the shareholder / manager corporate relationship and the condominium owner / RUM relationship, it appears the scope for a RUM's attitude to risk affecting a condominium's management is relatively small. Once built, the nature of a condominium's business is highly defined. Unlike corporations, it cannot move in and out of business activities with differing risk profiles. Apart from fairly isolated decision making issues such as whether to employ a provocative advertising campaign that is designed to garner "shock attention”, there appears little that a RUM can do to that would have a fundamental impact on a condominium's risk profile. Consistent with this view, no empirical observations highlighting management issues resulting from a differential in owner / RUM attitude to risk have been noted.

\section{CONCLUSION AND DISCUSSION}

When considered in the context of the tourism literature, two relatively novel dimensions are evident in this study. Firstly, despite the considerable growth in tourism accommodation provided by condominiums, no prior academic enquiry focussed on the use of condominiums for tourism has been found in the literature. Secondly, there appears to be a lack of studies focusing on the agency theory perspective on tourism business. 
With respect to the study's agency perspective, the only tourism-related empirical study that has been found to draw on the agency model is Guilding's (2003) investigation of capital budgeting issues arising in hotels. Application of agency theory in the tourism management context appears particularly overdue as twenty years have now elapsed since Jensen commented of the agency model: "the foundations are being put into place for a revolution in the science of organizations" (1983, p.319). Subsequent to Jensen's commentary, Ross (1987) described agency theory as the central approach to the theory of managerial behaviour.

This examination of the condominium unit owner / resident manager relationship provides a useful extension to the agency theory literature in several ways. Although the relationship exhibits many characteristics of the traditional business owner / manager relationship widely noted in prior agency theory studies, several key differentiating attributes arise when tourist-based condominiums are considered. These attributes include:

1) The principal (i.e., owners), do not comprise a homogeneous group with the same interests, but two distinct groups (resident owners and investor owners) with divergent interests. This is contrary to mainstream agency modeling which holds the basic presumption that owners have homogeneous interests.

2) Income generated from investment in holiday apartments is not pooled and then allocated based on proportionate owner interests held in the building. The resident manager, through his/her sub-letting role, determines the allocation of investment returns. This highlights the extent to which investor owner relationships can be characterised as occurring in a competitive context. As the backdrop of most agency modeling is the corporate world in which owners 
reap the benefits of their investment in proportion to their relative share of investment in a company, the potential for the RUM to mediate in the allocation of returns to unit owners represents a significant idiosyncratic aspect of the scenario reviewed in this study.

3) There appears to be considerable potential for agent moral hazard due to the incentive for developers to formulate condominium management rights contracts that favour the interest of the agent (manager) and a self-motivated disincentive for individual investor owners to take any actions that might adversely affect their relationship with a manager. These perspectives should be considered in the context of Bohren's (1998) view that agency model theorists have unduly overstated the presumption that agents and principals are indifferent to honesty, and have insufficiently recognised the potential of contracted agents to exhibit altruism. Sharma (1997) recognises the potential of professionals to have "pride in the craft and a calling to serve the public" (p.775-776). The potential of some RUMs to feel a calling to serve the tourist is not a far fetched notion, yet it is an emotion that is inconsistent with the agent model framework.

In light of the issues raised in this study, the following recommendations appear worthy of consideration.

1. One significant problem uncovered in the study appears to be the possibility of the RUM sub-letting units but not reporting the accommodation sale to the owner and therefore fraudulently retaining the accommodation rental received. A provision that could be implemented to lessen the potential of this activity occurring could be to recommend that in large tourist-based 
condominium complexes, investor owners hire an auditing agent to conduct periodic random reviews of the units occupied on a particular night. To facilitate this control, the RUM would have to be required to maintain an upto-date register of unit reservations and this register should be recorded in a form that enables real-time access by any investor owner. Such a system of control would also carry the added advantage of unit owners being able to check the occupancy levels of their unit with the occupancy levels of other units in the letting pool.

2. Inequitable allocation of sub-letting occupancy might be a significant factor restraining investment in tourism infrastructure. If an investor owner feels that a RUM is not managing the allocation of sub-letting equitably through the sub-letting pool, they will experience a reduced incentive to up-grade their unit. The main financial incentive for refurbishing an investment unit is the increased revenue generated due to the unit's improved standing relative to other units in the sub-letting pool. As a consequence, if an investor has a concern as to whether refurbishment will result in sufficient increased revenue, the likelihood of refurbishment occurring will be diminished. If this is a widespread phenomenon, the quality of accommodation provided to tourists will suffer. Because of this, so long as investor owners meet certain standards with respect to the quality of their unit's refurbishment and presentation, they should be entitled to an equitable proportion of the subletting occupancy sold by resident managers. A review of whether sub-letting has been distributed equitably across the letting pool should be facilitated by the resident manager making available a record of all sub-lettings made in the complex to any interested owner. 
3. Differences in the interests of resident owners and investment owners that have been highlighted in this paper may be sufficient to warrant legislation for the development of new strata title management modules restricted to particular owner types. For example, investment owner complexes could be distinguished from resident owner complexes. Such an innovation would circumvent governance problems resulting from conflicting interests of the two distinct owner categories. This distinction would facilitate local government zoning areas for investor owner complexes or owner occupied complexes. Development of particular condominiums solely focused on the provision of tourist accommodation may facilitate the design of common-use tourism focused facilities and also enable a tourism focused building to gain economies of scale in its sub-letting promotional and operating activities. ${ }^{8}$

4. Due to the divide that can result between investor and resident owners when a RUM controls the body corporate proxy voting rights of many investor owners, RUM's should not be entitled to attend or vote at body corporate owners’ meetings. Such an amendment would rectify a fundamental loss of RUM accountability which results from RUMs' enjoying considerable influence on who represents owners on the body corporate committee. A potential shortcoming of this suggestion relates to the problem of owner apathy. Without the RUM as a proxy option, many owners may find it difficult to identify a willing proxy, and achieving a quorum might prove increasingly problematical.

\footnotetext{
${ }^{8}$ Certain shortcomings of this proposal should also be noted. Firstly, as it is unlikely that legislation of this type would be retrospective, a proliferation of building types could result, i.e., resident, tourism, and mixed (resident and investor owners would continue to own units in buildings developed prior to the legislative change). Further, some investor owners might like to retain the option of becoming an investor owner in the future. As this model signifies a loss of owner flexibility, a negative impact on property values would result. In light of this, such a proposed module is likely to meet with stiff resistance from property
} 
A potentially fruitful strategy for the interested researcher seeking research topics that build on this exploratory enquiry into condominium management would be to review published studies in hospitality journals and to consider the extent to which condominiums might constitute a novel context in which to revisit the hospitality issues addressed. In light of the relative novelty of this study's research domain, one can conceive of a host of related avenues of original academic enquiry. A useful corollary study that has the potential to supplement our understanding of the issues reported herein could involve conducting interviews with a larger sample of resident unit managers. Resident unit managers could be presented with scenarios that underline some of the inherent conflicts between investor owners and resident owners as well as conflicts between resident owners and resident unit managers and asked about the incidence of such problems and how they might be best managed. Also, it was noted during the conduct of this study that the price setting of short-term stays in condominiums presents novel issues that are absent in hotel accommodation price setting. For instance, what is the nature of owner influence with respect to the pricing of short-term lettings when a unit is placed in the holiday letting pool? Also, to what extent do variations of the quality of refurbishment in units result in short-term letting price differentials? Another novel area of research enquiry could focus on issues surrounding the setting and collection of condominium sinking fund (long-term property maintenance) owner contributions. 
FIGURE 1

The unit owner/resident manager agency relationship in a tourist-based condominium

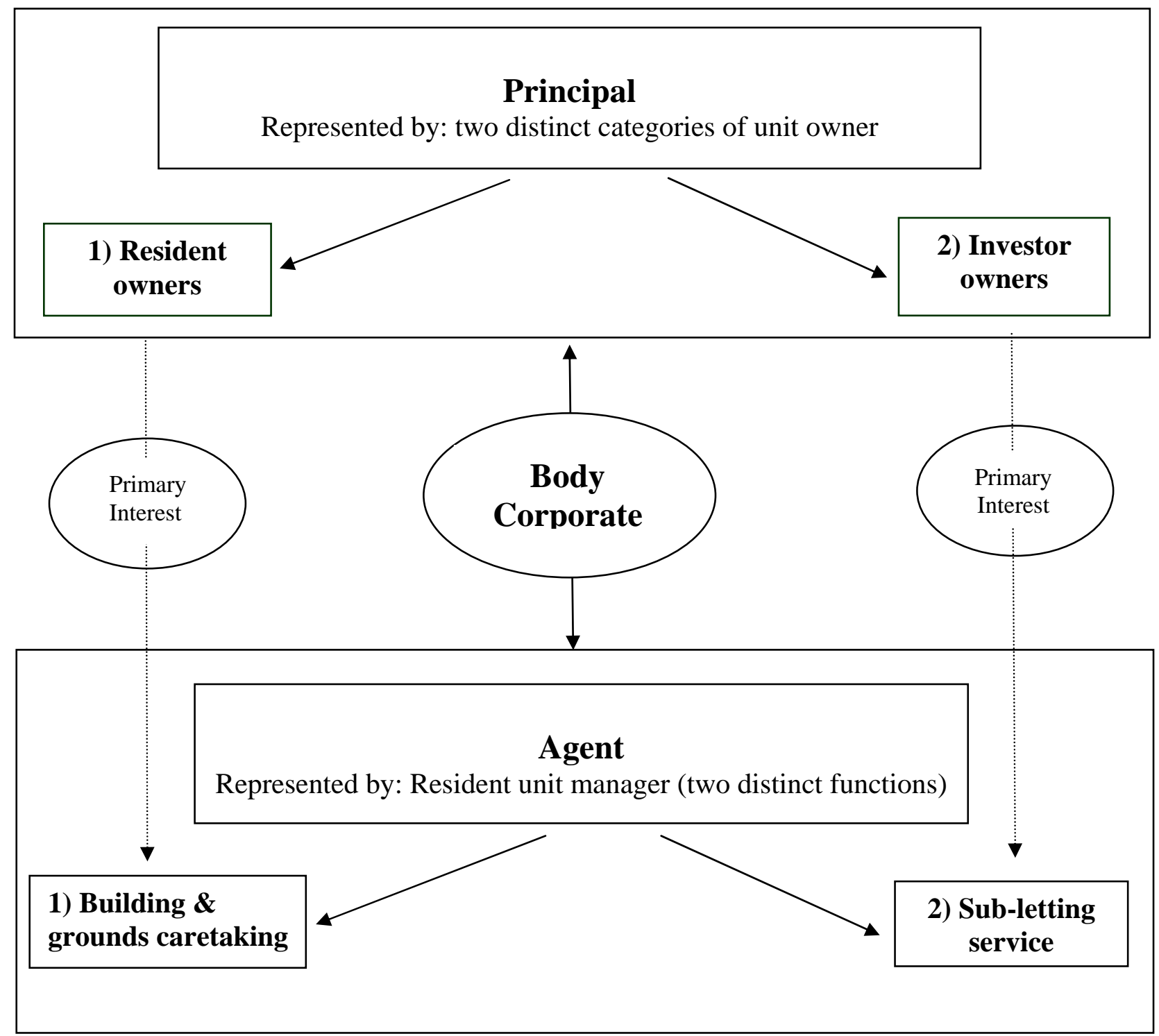




\section{REFERENCES}

Australian Bureau of Statistics (2002). Tourist Accommodation, Series 8635, March Quarter 2002. AGPS, Canberra.

Baker, G. P., Jensen, M. C., and Murphy, K. J., (1988). Compensation and incentives: Practice vs. theory. Journal of Finance, 43(3), 593-616.

Basu, A., Lal R., Srinivasan, V., and Staelin, R., (1985). Sales-force compensation plans: An agency theoretic perspective. Marketing Science, 4, 267-291.

Bazerman, M.H., Neale, M.A., Valley, K.L., Zajac, E.J, and Kim, Y.M., (1992). The effects of agents and mediators on negotiation outcomes. Organizational Behavior and Human Decision Processes, 53, 55-73.

Bergen, M., S. Dutta, and O.C. Walker, Jr (1992). Agency Relationships in Marketing: A Review of the Implications and Applications of Agency and Related Topics, Journal of Marketing, 58, 1-24.

Berle, A.A., and Means G.C., (1967). The modern corporation and private property, New York: Harcourt, Brace \& World.

Bohren, O., (1998). The agent's ethics in the principle-agent model, Journal of Business Ethics, 17(7), 745-755.

Cotter, J.F and Zenner, M., (1994). How managerial wealth affects the tender offer process. Journal of Financial Economics, 35, 63-97.

Demski, J. and Feltham, G., (1978). Economic incentives in budgetary control systems. Accounting Review, 53, 336-359.

Eisenhardt, K. M., (1988). Agency and institutional explanations of compensation in retail sales. Academy of Management Journal , 31, 488-511.

Eisenhardt, K. M., (1989). Agency Theory: An Assessment and Review. Academy of Management Review , 14(1), 57-74.

Fama, E. and Jensen, M., (1983). Separation of ownership and control. Journal of Law and Economics, 26, 301-325.

Guilding, C., (2003). Hotel owner / operator structures: implications for capital budgeting process, Management Accounting Research, 14(3), 179-199.

Jensen, M., (1983). Organization theory and methodology. Accounting Review, 56, 319338.

Jensen, M., (1984). Takeovers: Folklore and science. Harvard Business Review, 62(6), 109-121. 
Jensen, M. and Meckling, W., (1976). Theory of the Firm: Managerial behavior, agency costs and ownership structure. Journal of Financial Economics, 3, 305-360.

Jensen, M. and Roeback, R., (1983). The market for corporate control: Empirical Evidence. Journal of Financial Economics, 11, 5-50.

Kakabadse, A. and Kakabadse, N., (2001). The Geopolitics of Governance, Hampshire: Palgrave.

Kesner, I.F., Shapiro, D.L., and Sharma, A., (1994). Brokering mergers: An agency theory perspective on the role of representatives. Academy of Management Journal, 27(3), 703-721.

Lambert, R. A., (2001). Contracting Theory and Accounting, Journal of Accounting and Economics, December, 3-87.

La Porta, R., Lopez-de-Silanes, F. and Shleifer, A., (1999). Corporate ownership around the world, The Journal of Finance LIV (2), 471-517.

Letza, S. and Smallman, C., (2001). In pure water there is a pleasure begrudged by none: on ownership, accountability and control in a privatised utility, Critical Perspectives on Accounting 12(1), 65-85.

Mills, P. K., (1990). On the quality of services in encounters: An agency perspective. Journal of Business Research, 20, 31-41.

Ross, S. A., (1987). The Interrelations of Finance and Economics: Theoretical Perspectives, American Economic Review, 77, 29-34.

Russell, R. and Faulkner, B., (1999). Movers and shakers: chaos makers in tourism development, Tourism Management, 20(4), 411-423.

Sharma, A., (1997). Professional as agent: Knowledge asymmetry in agency exchange. The Academy of Management Review, 22(3), 758-798.

Stoney, C. and Winstanley, D., (2001). Stakeholding: confusion or utopia? Mapping the conceptual terrain, Journal of Management Studies 38(5), 603-26.

Walker, G., and Weber, D., (1984). A transaction cost approach to make or buy decisions. Administrative Science Quarterly, 29, 373-391.

Walsh J.P and Seward, J.K., (1990). On the efficiency of internal and external corporate control mechanisms. Academy of Management Review, 15(3), 421-458.

Warnken J., (2002). Tourism Infrastructure Audit - Gold Coast, Project 2.2 of the Gold Coast Visioning Project CRC Research Report Series, Co-operative Research Centre for Sustainable Tourism, Griffith University Gold Coast.

Warnken J., Russell, R and Faulkner, B., (2003). Condominium Developments in 
Maturing Destinations: Potentials and Problems for Long-Term Sustainability. Tourism Management 24(2), 155-168.

Williamson, O. E., (1985). The Economic Institutions of Capitalism, New York: Free Press.

Zingales, L., (2000). In search of new foundations, The Journal of Finance LV(4), 162353. 